\title{
Analysis of Worship, Faith-Healing and Prophesy in the ADC Church
}

\author{
Pamela Kima \\ Social Sciences Education Department \\ Masinde Muliro University of Science and Technology \\ P. O. Box 190 Kakamega, Kenya \\ Pamelakima@Gmail.Com
}

\begin{abstract}
African independent church movement is a phenomenon that has origins on the African continent and is closely associated with colonialism. The theology of these churches is lived and sung, they put emphasis on the power of the Holy Spirit and faith healing. Besides these churches have not abandoned their traditional practices in relation to death. This article arises from the fieldwork that adopted a descriptive research with Hamisi district in western Kenya. Data was collected using questionnaires, oral interview and participatory observation. This in depth study details aspects of worship in relation to prophecy and faith healing and death in the African divine church.
\end{abstract}

Keywords: AICS African Independent Churches, ADC African Divine Church, GS General Secretary, MAs Mother Assemblies, MVs Mother Villages, SSTs Sunday School Teachers.

\section{INTRODUCTION}

These new Pentecostals offer personal encounter with God through the power of the Holy Spirit, healing from sickness and deliverance from evil in all its manifestations, social and spiritual aspects that makes them be regarded as AICs. This is because they were founded by Africans for Africans and led by Africans. These churches are largely independent of foreign churches, they are self-governing, self propagating and, to a lesser extent, self supporting. They have no organizational links with any foreign churches hence regarded as modern version of older AICs. The believers in these churches are empowered through baptism of the Holy Spirit to overcome the ills of life. Provision is also made for any person to become a prophet and therefore, is a custodian of spiritual power. These churches are christocentric and lay an emphasis on personal encounter with Christ that is, being born again, the use of spiritual gifts like speaking in tongues, and to a lesser extent, prophecy (Allan, 2001).Besides these churches still value their traditional practices in relation to death even after they accepted christianity.

New religious movements are the fastest growing movements of Christianity in Africa. These movements have continued to flourish even after the death of their founders. To the dismay of many researchers, this impressive growth has sometimes been at the expense of the older European Mission churches. It is also hard to understand why AICs that arose as a protest to colonialism have kept flourishing long after the end of colonial era. Although the ADC is an African Independent Church that emerged during the colonial period, it did not arise due to protest against colonialism. The ADC was a protest to missionary Christianity due to its focus on African spiritual autonomy and personality.

\section{RESUlTS AND DISCUSSION}

\subsection{Theological Aspects of ADC with Specific Reference to Worship, Faith Healing and Prophecy}

\subsubsection{Worship}

Worship expresses the response of a religious person to the holy as one apprehends it (Nandi, 1993). There are many and various ways African peoples report to their spiritual world of which they are aware. This response generally takes on the form of worship, which is externalized in different acts and sayings. These acts may be formal or informal, regular or communal or individual, ritual or un- 
ceremonial. They vary from one society to another and from one area to another. Africans in traditional African societies had what, when, how and where they worshipped God (Mbiti, 1969).

\subsubsection{Worship in African Independent Churches}

In new religious movements, their theology is lived and sung. This means that this theology is not written down. In AICs written theology is not a priority and is generally less formulated in these churches than in European instituted churches. Foundational to these churches are definite theological presupposition found more in practice of their Christianity than in formal dogma (Allan 2001).

AICs have specific attire for worshipping for example, members wear flowing robes and turbans, practice constant singing and dancing, emphasize spiritual possession, observe Old Testament dietary and purification taboos. They are also known for their joyful and colourful procession and open air meetings in which flags, drums and trumpets are used in singing to traditional African tunes adds Allan.

Worship in these churches is done anywhere that is, on roads and market places. The songs sung, are not found in hymn books. Worship is done spontaneously that is people sing, dance, bit drums, jump and clap hands at the same time.

\subsubsection{Worship in ADC}

Like other AICs, worship in ADC is done anywhere for example on roads and market places. Worship is spontaneous and ADC gives its members spiritual autonomy that is the members can sing, dance, clap hands, jump and bit drums freely without being limited in their worship. Theology of ADC is lived and sung. This is because, no training is done to make one a Soloist, a drum beater, a flag carrier, how to clap hands and dance during worship among others. These aspects come out naturally during worship (OI with MR on 20/08/2012). ADC offers employment to its members for example construction work at the mission, a priority is given to ADC members who have the skills and women are given casual work to fetch water for the construction (OI with one female member on 7/12/2012). The researcher found out that ADC theology is lived and sung which propagates both African and Christian beliefs leading to the spread of the church.

My findings revealed the following about theological aspects with specific reference to worship, faithhealing and prophecy. In relation to worship, my findings revealed that in ADC, a programme for worship is circulated to all ADC branches from the Headquarters. ADC has four services held throughout the week. The language used in worship is Kiswahili and Kiluhya. Worship is characterized by singing and dancing, beating of drums, metallic instruments and clapping of hands. Church leaders put on their official attire and members their church uniform.

Songs sung are conducted by women. Most of the songs are own composed and a few have been borrowed from missionary churches found in hymn books. Singing addresses the psychological and emotional problems of women. Testimonies are also part of worship. People than other members for intercessory prayers and God for enabling them overcome various challenges they were facing. Different types of offerings are given in church for instance, alms, beans, tithes and maize. To attract the attention of the congregation, pastors use various methods among them signing of choruses and telling of stories that leave members in suspense at intervals. Sunday worship is the most important because those who are unable to attend the week day services get a chance to attend. The testimonies given by various members indicate that God answers their prayers. The spread of ADC can be increased if more pastors are trained. There is no standard time for starting worship each church has its own time.

Sunday school service is very important because it is the foundation of the future church. Children are given time to learn future roles for example singing, beating of drums and rehearsing biblical verses. Sunday school children have been divided into classes according to their ages for instance those below class five. This is to make teaching easy. From the foregoing discussion, our forth conclusion is that ADC theology is lived and sung. It is lived through the ways members relate to one another for example, they share their resources by assisting a member who is bereaved. This is done through contributions of money, food stuffs and moral support. It is sung through the songs that tell who God is, believing in Jesus as the son of God, Jesus as the vine, life after death and trusting in God as the creator, provider, protector, comforter and Holy. 


\subsubsection{Prophecy in African Independent Churches}

Prophecy is the act of delivering the truth as revealed by God. Prophecy is an utterance which is inspired by direct revelation from the Holy Spirit. In the Old Testament times, prophets were called to deliver Yahweh's message for specific situations. They would tell the people of Israel what God was going to do and what He required of them in a particular situation. The O.T prophets also predicted what was going to happen in the future (Kerre et al, 2006).

Prophecy is also recognized in the New Testament as a gift of the Holy Spirit (Romans 12:6). In the O.T there were both major and Minor Prophets who were regarded as true prophets. These true prophets were referred to as true because majorly they received a call and revelation from God and their prophecies came to pass among other characteristics (Kerre et al, 2006).

It is also necessary to unearth situations under which the prophecies were made. In the O.T God sent His prophets to go and deliver His messages in different situations, for example;

1. To warn the people of Israel about God`s impending danger.

2. They foretold the future.

3. Condemned evil deeds in the society.

4. Were the consciences of the people?

These prophets were the messengers of God and their prophecy was given by God (Kerre et al, 2006). In AICs, prophecy is one of their characteristics. It is one of the gifts of the Holy Spirit given to the church members. People with this gift of the Holy Spirit are highly appreciated and respected because of their contribution to the churches. Some of the AIC churches were founded with leaders who had the gift of prophecy that attracted people to these churches (Allan 2001). In some churches the founders are prophets and whatever they foretell, come to pass (Nandi 2001). It is basing on this background that the researcher aimed at examining prophecy in ADC.

\subsubsection{Prophecy in $A D C$}

In the initial years of ADC that is in the 1950s and 1960s prophets were highly respected because their prophecy came to pass. For example in the 1970s, a prophecy was revealed to two women who had been barren that they would conceive. This prophecy came to pass and these two women gave birth to a baby boy and a baby girl. These two women to whom the prophecy was made have remained ADC members' to-date. Like in other AICs prophecy is not unique to ADC for it was a key feature in the initial years.

Today prophecy has declined in ADC. For one to be a prophet, he or she must spent time fasting and praying and lead a righteous life before God. This is something that has defeated most Christians to fulfil (O.I with Rev. Tiegu on 23/08/2012). It is basing on this that the researcher aimed at finding out what has gone wrong that has made prophecy to decline in ADC, yet initially it was an attracting factor to the ADC. The findings revealed that prophecy is almost non -existent.

\subsubsection{Faith Healing In African Independent Churches}

Faith healing is healing through spiritual means. Believers assert that, the healing of a person can be brought about by religious faith through prayer and/or rituals that, according to the adherents, stimulate divine presence and power towards correcting disease and disability. This is done through ritualistic practices of communal prayer and gestures. Such as lying on of hands that are claimed to solicit divine intervention in initiating spiritual and literal healing (Keefauer, 2009).

Faith healing is a common feature of many new religious movements (Nandi 2001). Since faith healing and prophecy are a characteristic of religious movements, some churches have been named faith - healing churches or spiritual churches because of the emphasis they place on spiritual power and have historical and theological roots in the Pentecostal Movement. Examples of these churches include; African Israel Nineveh Church (AINC) and Akurinu (Allan, 2001).

Faith healing is an essential part in of life of AICs because problems such as sickness, witchcraft and poverty among others affect the whole church communally. In many AICs the prophet healer has taken over the function of the traditional healer. These prophets - healers use symbols such as holy water that is sprinkled to the people as a ritual of purification or protection. Holy water is also sprinkled on cars, school books, houses and food among others. 


\subsubsection{Faith Healing in ADC}

Like in other AICs, faith healing is not a unique feature in ADC. Faith healing is one of the factors that have led to numerical increase in the church. From the testimonies given by church members, it is evident that faith healing is practiced. Members of ADC give testimonies thanking God for being healed of their various ailments such as paining knees, headaches and stomach aches among others. Hence this shows that faith healing is one of the factors that have led to numerical increase of the church. Faith healing is done through lying of hands on people with various ailments and prayers are made asking God to heal the affected persons (O.I with Rev. Tiegu on 23/08/2011). The researcher found out that faith healing is present in ADC and that it is one of the factors leading to the spread of the church.

\subsection{Beliefs and Practices in ADC in Relation To Death.}

\subsubsection{Death}

This is the last rite of passage for all human beings. Therefore, ADC carries out the burial rites depending on the ADC constitution, age, and how committed the dead was to the church. This means that, the burial of a child is not as elaborate as that of an adult who is a full member of the church in terms of having undergone the church rites like dedication, baptism and paying all the church requirements like tithes and annual subscription for every member (FGD with CVs on, 26/08/2011).

Immediately one dies, the body is washed by the family members and treated well to slow down decomposition before burial. This is also because, it is believed that, the dead is a living dead, hence needs respect. Otherwise, he or she can come back and complain for being sent off without cleaning. The deacon is informed and the dead is put outside on the veranda of the house by the deacon with the help of other male clan members. In ADC, death is not natural; there is always a cause for death for example people are bewitched (FGD with female members on, 2/08/2011). The Chief Vicars say that, those are traditional beliefs about death but Biblically death is a must for all of us. This is the view held by ADC church (O.I with CVs on, 24/08/2011).

\subsubsection{Funeral Rites in ADC}

These are conducted with some varying details depending on age, sex and status of the individual in church. The researcher attended three funeral rites:

- For a child under ten years.

- A grown up who was baptized, married but died not paying church subscriptions and rarely attended church services.

- An adult full member of ADC who had undergone all the church rites and paid all the church subscriptions.

In these three funeral rites the procedures are the same with a few variations here and there. A child's service is not long and Burial is conducted by a pastor and singing led by Mother Assembly during burial. This is because the child is below 18 years. In the second one, the service is long enough but the dead is buried by the village deacon and singing led by Mother Village. During burial, at the grave side, the deacon only says the Lord's Prayer and reads from the book of Psalms 123. This is because the man was not a full member of the church (O.I with MVs on, 9/09/2009). The third burial, which is the concern of our study, is done in an elaborate and official way. Burial is conducted by the Chief Vicar following ADC's burial procedures as laid down in the constitution for example observing burial time, not being biased on the speakers and following the person's contribution to church among others. The various leaders also attend the burial dressed in their official attire.

When death of a church member takes place, father village is informed who then relays the message to mother village. Mother Village then passes the information to Mother Assembly who in turn passes the information to her pastor and the pastor then relays the information to mother region, who further relays the message to the Chief Vicar and finally to the head office. This eases the flow of information from grass root onwards to organize for funeral arrangements. Communication is easy because all ADC leaders have phones and even emails (O.I with G S Rev. Mahero on, 6/12/2011). Members also pass information verbally from one person to another. Church members keep the night vigil with the bereaved family, singing and dancing to keep the bereaved company so that, they do not think of the dead so much. Songs also play a therapeutic role to the bereaved. Some of the songs sung show that 
death is for us all because to see God one must die and God gives us free days to live on earth. This means, ADC believes that, God is the giver of life. For example:

Soloist: Mbeveywi imieli gya vutswa, (I have been given free days)

All: No budiku be liluhitsa (And nights of tiredness)

Lwa ngonanga hasi ndevanga, (As I sleep,)

Ndatula inyinga ki? (I wonder when I will leave)

Chorus; Ndilonda kuinzila, (The path)

Ya vaguta vatsira ku, (The victors followed)

Lwa ndiduka hakilyango, (When I reach the gate,)

Nditevwa idigidi. (I will be asked for a ticket)

Soloist: Sindalola vulahi mba, (I will not feel comfortable)

All: $\quad$ Imoni ya uyu endolanga, (Those who so me)

Si nyala kandi kondola mba (Will no longer see me)

Si ndava hano kandi (I will not be there)

Soloist: Sindirana mu nyumba yange, (I will not go back to my house)

All: Hango hange si halamanya, (My home will not recognize me)

Lwa madiku gange gaheri, (When my days shall come to an end)

Kilindwa kila mbugula. (My grave will take me)

Soloist: Mmbiri gwange ne tsing'ende, (My body is maggots)

All: $\quad$ Na machindi ga malova (And lumpsomes of soil)

Ligodo lyange livoheywi, (My skin is numb)

Kandi liyavuguki. (And falling off)

Source: Own composed

I have been given free months to live and a night of tiredness. As I sleep I ask myself what time I will leave. I will not be happy because the eye of the person who sees me will not see me again. My home shall not recognize me again because my days have ended on earth. My body is full of maggots, and my skin has sores. When I die I will follow the path the victors in Christ followed. When I reach the gate in God's Kingdom I shall be asked for a ticket to guarantee my entrance. This means that we shall all follow the path the victors in Christ followed and when we arrive at the gate in heaven, we shall be asked for a ticket to guarantee our entrance to the kingdom.

Before burial of the dead, Mother Village organizes for everything with the help of the family members. She requests church members to bring to the bereaved foodstuff, money, water, firewood and offer assistance in cooking to feed visitors from various parts. There is a book in which members of ADC are to record their monetary contributions to the family. This shows that church members are in unison with the bereaved family members. Beside the dead there is ADC flag with white, red, green and stripes. This shows that the dead is a full member of ADC (O.I on, 10/10/2011 with MVs).

\subsubsection{Digging of the Grave}

Digging of the grave is initiated by a clan elder who then gives a go ahead to willing men to continue. A grave is rectangular in shape and it is usually 4 by 6 feet. Traditionally, women are normally buried on the right hand side that is, as you leave the house because it is believed that women die in the bedroom and the bedroom is normally placed on the right hand side of the house hence, their rightful position for burial. It is also believed that men die while in the sitting room which is on the left hand side as you enter the house, thus justifies the left hand side as you leave the house the rightful place for burial of men. There are some who do not follow burial sites, hence they have set aside a grave yard where all family members are buried regardless of gender. A place where the grave is dug and 
who digs it has nothing to do with church. They only need a grave to bury the dead. (FGD with CVs on, 26/08/2011). This shows that members of ADC, practice their traditional beliefs and practices for example, observance of burial site based on gender, age and status in the family.

\subsubsection{Burial/Funeral Programme}

A Funeral programme is conducted according to laid down rules of ADC. The programme includes the following:

- Removal of the bereaved from the house to join the congregation outside.

- Everybody stands up as the bereaved arrive where the congregation is seated.

- An opening prayer by any of the pastors assigned to do so is made.

- Three songs are sung, led by Mother Assembly of the area of jurisdiction.

- A verse read from the Bible by any appointed pastor and prayer after.

- Welcoming the speakers (the bereaved) by a song sung by Mother Assembly of the area.

- Neighbour to the deceased.

- Provincial administration who welcome any other visitor in the line of administration, for example, a member of parliament, councillors among others.

- The church: - Father village, mother village, mother assembly, mother region, Pastor, Vicar, Bishop.

- Reading of the eulogy.

- Offering for the bereaved.

- Preaching

- Closing of the ceremony with a prayer by the master of ceremony.

- Procession for burial.

Burial programme starts at 10.30 a.m. and by 3.30 p.m. burial should have been done. This service time is not fixed at times, the weather dictates the burial time. During rain seasons for example, the programme is rushed to avoid people being rained on. The master of ceremony is not based on the speakers. The speakers, both men and women are accorded equal time and chance.

This programme involves relatives, neighbours, friends and members of provincial administration. All are allowed time to address mourners on matters concerning life history of the deceased. Most speakers exhort good virtues of the deceased and urge the audience to lead upright lives. Others advise the bereaved family to be courageous and live peacefully with one another. The Provincial Administration highlights general issues concerning security in the area for instance brewing of illicit liquor, theft and the threat posed by the spread of HIV and AIDS to the society. Allocating time to people of different category indicates that, the dead belongs to the whole community and not just the church and the family.

The programme favours both men and women to give speeches. Children of the deceased are addressed extensively by almost all speakers and urged to be as good as the deceased. They are also advised to attend church services because they had not been doing so. Key speakers are welcomed with a song. When a speaker utters something that is unpleasant to the congregation, there is booing and a song is sung to calm the crowd before the speaker continues. Similarly when a speaker takes more time, the crowd becomes restless and he or she is stopped by a song being sung by the crowd. Songs are used to dominate the mournful atmosphere and are accompanied by dancing, jumping and clapping of hands. This is to make the bereaved not to feel lonely for losing a loved one.

ADC speaker who is a Chief Vicar is the Main Speaker of the day dressed in his official attire, a yellow robe with red and green strips on the bodice, white cap with red and green stripes and red in the middle. The speaker is an eloquent character, whose oratory skills enable him to capture attention of mourners on that burial day. He is a counselor, who encourages the bereaved family to remain strong in the face of death. 
The preacher is the advocate of ADC. He highlights the beliefs and practices of ADC. The speakers generally, speak well of ADC and use that opportunity as a recruitment drive for new members. It is not only for $\mathrm{ADC}$, but the advice encourages people to go to any church so long as they are worshipping the true God. Sermon of the day is meant for the people who have attended the burial. The preacher says that he has left the dead in God's hands as the final judge. He urges those willing to join ADC to do so. The speaker disassociates ADC with vices such as smoking of bang, alcoholism and unfaithfulness among others. The speaker also requests those who have not accepted Christ as their personal saviour to do so. He asks people to change their ways and prepare themselves for the coming of Christ in order to escape God's judgements.

When the preacher is through with preaching that is done in Kiswahili and Kiluhya, the pall bearers are called upon and prayed for. A procession for burial is made and only those with white clothes are to join the procession singing and dancing. The casket is carried to the door of the deceased house and the preacher reads from (Job 7:7-10). That our lives are like a breath and our happiness wanes to an end, death makes one not to be seen again and is forgotten by all who knew them. This means that the dead is bidding bye to his house and those who knew him. In ADC, these verses show that death separates people from those who knew them. Carrying the casket to the deceased door, means that he is bidding farewell to family members.

While on procession, the Reverend in charge of the burial reads various verses. This time the casket has been carried shoulder high between two lines. This symbolizes that the dead was a righteous man and has a direct ticket to eternal life. The Reverend conducting burial reads from the book of (Job 1:21-22). We were born with nothing and we shall die with nothing, the Lord gave and has taken away, his name be praised. This verse shows that, ADC believes that God gives life and takes it away. When we die we are buried with nothing, that is, we leave our family members and all material things acquired while on earth.

When the procession reaches the graveside, the casket is placed on top of the soil and the Reverend reads from the book of (Job 17:1-2) that the end of our breath has come and the grave is ready for me. This shows that when we die we are buried and the grave becomes our resting place. After the casket has been lowered in the grave, the Reverend reads from I Corinthians 15:35-49 that the first Adam was created a living being but the last Adam is the life giving spirit. It is not physical and then spiritual, the first Adam made of earth came from earth, the second Adam came from heaven. To ADC, this is an approval that we were made from soil and to soil we shall return. This indicates that when one dies, the body remains in the grave while the soul goes to heaven. Burial of the dead is done in accordance with the biblical requirements that, we shall return to the soil from which we came. Those who belong to the earth are like the one who was made of earth. Those who are of heaven are like the one who came from haven. The Reverend then takes soil on a spade and throws it on the coffin in the grave three times reading from Genesis 3:19 that we were made from soil and to soil we shall return. The second time Reverend says dust to dust and the third time ash to ash and the soul in eternal life. When the grave is half way filled, the Reverend reads from John 5:28 that, time is coming when all the dead shall hear his voice. To ADC, this verse indicates that there is life after death because the dead shall hear God's voice and resurrect, after which God will judge people according to their deeds. After the grave is filled to the brim, the Reverend reads from Timothy II 4:6-9 that I have done my best in the race, I have run the full distance and I have kept the faith and now there is a prize awaiting me, of being put right with God which the Lord righteous judge will give me on that day. This means that after death, Christian who had lived righteous lives shall be rewarded by God in his kingdom with eternal life. This verse also motivates ADC members to do good so as to be rewarded with eternal life by God.

After this reading, a song is sung and wreathes, laid on the grave. Lying of wreathes on the grave is a sign of last respect, love and biding bye to the dead. Wreathes are planted by MV who is a widow. This is because traditionally it's believed, if one who is not a widow and plants flowers for a widower on the grave, her husband will die as well hence it must be a widow to plant (OI with MRs on, 24/08/2011).

$\left.\begin{array}{ll}\text { Soloist : } & \text { Taji imewekwa tayari taji } \\ \text { All }: & \text { Taji imewekwa tayari taji }\end{array}\right\}$ (A prize is ready)

Soloist : $\quad$ Taji ya uzima imewekwa tayari taji (A Prize of everlasting life is ready) 


\begin{tabular}{lll}
\hline All & $:$ & Taji uzima imewekwa tayari taji (A prize is ready) \\
Soloist & Taji ya ushindi imewekwa tayari taji ( A prize of victory) \\
All $\quad:$ & Taji imewekwa tayari taji (A prize is ready) \\
Soloist : & Taji ya baba imewekwa tayari taji (A prize for my father is ready) \\
All : & Taji imewekwa tayari taji (A prize is ready)
\end{tabular}

\section{Source: Own composed}

A prize has been put ready, a prize of life and a prize of victory.

After planting wreathes, there is dancing and singing around the grave. The songs that are sung are to bid farewell to the deceased. For example:

Soloist : $\quad$ Ahananga hango kwaheri (His biding his home goodbye)

All : $\quad$ Kwaheri x2 Kwaheri kalunu lelo, kwa heri x2 (goodbye, today goodbye)

Soloist : $\quad$ Mulindi wa hango yazanga (The protector of the home is coming)

All : Yazanga, yazanga, mulindi wa hango yazanga, yazanga (The protector kalunu lelo.

Of the home is coming today)

Soloist : $\quad$ Lelo (Today)

All : Yazanga, yazanga, yazanga kalunu lelo. (He is coming coming, his coming today)

Source: Own composed

That the deceased who was the care taker of the home, has given goodbye to the home then

After singing Mother Region and Chief Vicar take the bereaved to the house, pray for them and hand the offering to them. They are advised to eat, drink and forget about the dead for we shall meet him when the trumpet will sound. The people then disperse and start serving the mourners who have turned up for the burial. After burial, a few people remain in the home for three days. On the third day, church members come as early as six a.m. to conduct a resurrection service. Songs are sung in relation to resurrection accompanied by drumming and dancing. For example;

Soloist: $\quad$ Nziye kulola hayavikwa haleluyia x2

All : Haleluyia nziye kulola hayavikwa

Soloist: $\quad$ Yesu ni mwana wa Nyasaye haleluyia x2

All : Yesu ni mwana wa Nyasaye haleluyia

(Jesus is the son of God Halellujah)

Soloist: $\quad$ Yesu si yali ne mbodoka haleluyia x2

All : Yesu si yali ne mbodoka haleluyia.

Soloist: $\quad$ Yesu yaginga msalaba haleluyia $\mathrm{x} 2$

All : $\quad$ Yesu yaginga musalamba haleluyia.

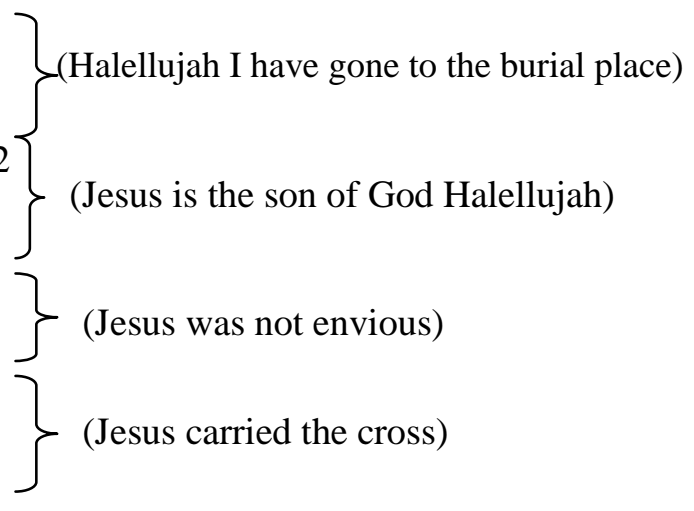

Source: Own composed

That I have gone to see where he was buried halelluja, Jesus carried the cross halelluja, Jesus was the son of God and that Jesus was not jealous halelluja. This further shows that ADC believes in life after death.

Various books are also read on this day, such as, Luke 24:1-12. That very early in the morning on Sunday, the women went to the tomb carrying spices but they found the stone rolled from the grave. They were puzzled but the angel told them that Jesus was not there for he had resurrected. To ADC, the resurrection service held on the third day after burial is justified because, after the burial of Jesus on the third day + women had gone with spices to apply on his body only to find that he had resurrected. This implies that, ADC believes in life after death, a view shared by both traditional African society and Christianity. After the service, church leaders are offered some food and drinks and they leave. Other rituals done on this day are not part and parcel of the church. It is the family 
members who conduct them by themselves for example, shaving of hair, (O.I with Rev. Kidagale on, 26/08/2011).

Shaving of hair according to ADC has various significances as follows: marks the separation of the dead from family members, when hair starts to grow signifies beginning of a new life without the deceased, a sign that, family members were bereaved. The sharing of the deceased property like clothes signifies the absence of the dead in the family. Mentioning of creditors and debtors is to make the dead go in peace to avoid visions from the deceased concerning his creditors and debtors. These rituals indicate that although ADC split from PAOC a missionary church, it has borrowed some African post burial rituals. This justifies that, ADC is an African Church which still retains some specific aspects of African culture in relation to death.

Before burial, it is announced by the Master of Ceremony when the 40th day commemoration ceremony would take place. On finding out why specifically after 40 days and not before or after, the researcher learnt that after the resurrection of Jesus, he stayed on earth for 40 days before ascending to heaven. Similarly, that is done because as Christians, it is believed that just as Jesus ascended to heaven after 40 days so does the deceased. Hence the deceased has bid farewell till resurrection time (O.I with Rev. G.S Mahero on, 15/07/2012). This implies that ADC has borrowed some aspects and values of PAOC but still has respect for African cultural practices. On that day, the service is conducted by ADC leaders, singing and dancing is done to give the last goodbye to the deceased and told to go for good and wait for the resurrection day. There is feasting, a bull is slaughtered and people rejoice. This is because there is no mourning any more. The feasting is also meant to please the dead so that the dead does not come back demanding for a good send off in terms of feasting. Feasting also indicates that the wealth the dead had accumulated has been shared with mourners in terms of foodstuffs. According to traditional African society, this is done in order for the deceased to let his family members enjoy his wealth after he has died. On that day, the pastor also reads verses from various books of the Bible such as Mark 16:19-20 that he was received in heaven and sat on the right hand of God. To ADC, this shows the belief that life does not end with death we shall continue to live with God in his kingdom. This also urges ADC members to live righteous life so as to inherit God's kingdom.

A programme is also drawn for the day. Only a few people speak and are advised not to repeat whatever they had said during burial. There are other rites that are done on this day for example shaving of hair, sharing of the deceased property and mentioning his debtors and creditors. These are strictly done by family members and clan; the leaders of the church have no role to play in them. On finding out why the church does not participate in these rituals, the researcher learnt that their role is to conduct the service as per ADC constitution and leave, but if offered food they eat. (O.I with Rev. Kidagale on, 26/08/2011). From this burial rites the findings revealed that, ADC is syncretic in that both Christian practices for example, reading the bible at the grave side and traditional such as, shaving of the hair, observing burial sites for the dead, sharing property and mentioning of debtors and creditors to the deceased are followed.

\section{RECOMMENDATION}

In view of the above findings on theological aspects in relation to worship, faith-healing, prophesy and death my conclusion was that ADC theology is lived and sung, and that ADC practices both Christian and African death rites. The researcher therefore suggests that a research be done in other African churches on their theology and death practices.

\section{MethodS}

The research design used was descriptive or qualitative analysis. The major purpose of descriptive research is description of the state of affairs as it exists. Descriptive studies often result in the formulation of important principles of knowledge and solutions to significant problems. Descriptive research is a process of collecting data to test hypothesis or to answer questions concerning the current status of the subject of study (Kinoti, 1998).

A descriptive study is undertaken in order to ascertain and be able to describe the characteristics and the situation, (Sekaran, 2004). A descriptive survey is a method of collecting and analyzing information by interviewing or administering a questionnaire to a sample of individuals. The information is obtained from a sample rather than the entire population at one point in time, which may range from one day to few weeks. The study employed descriptive analysis to establish opinions 
and knowledge about ADC. The researcher analyzed the historical background, examined the beliefs and practices in relation to marriage and death, assessed the role of women in leadership and investigated the theological aspects of ADC in relation to worship, prophecy and faith healing. Any research undertaking involves lots of implications hence this design was deliberately selected for the study because such descriptive method allows for quick data collection at comparatively cheap cost, (Grinnel, 1993). The researcher also employed quantitative or statistical analysis. In this method, the researcher calculated percentages of various responses from the oral interviews, focus group discussions from the interviewees and statistics from the registry department on leaderships and membership composition. In using qualitative analysis of data, the researcher was interested in analyzing information in a systematic way in order to come to some useful conclusions and recommendations, (Mugenda and Mugenda, 1999).

\subsection{Area of Study}

Hamisi District formed the area of study. The headquarters of Hamisi District is at Hamisi. Hamisi District is a cosmopolitan district inhabitated by Tiriki, Maragoli and the Terik people. Hamisi District is divided into two divisions; Tiriki East comprising Shaviringa, Shamakhokho, and Banja; and Tiriki West comprises Gisambai, Tambua, Jepkoyai and Gamalenga. The climate is mainly tropical, with variations due to altitude. The district is a home of many new religious movements and mission churches among them ADC, African Israel Church Nineveh, and Pentecostal Assembly of Canada among others respectively. The district has a population of about 142,000. The study was limited to investigation of the theological aspects such as worship, prophecy and faith-healing .

\subsection{Study Population}

The target population of this study was the Archbishop, the General Secretary (GS), the Male Leaders, the Female Leaders, the Mother Assemblies (MAs), the Mother Villages (MVs), Sunday School Teachers (SSTs) and the female members of the congregation.

\subsection{Sampling Procedure and Techniques}

Hamisi District has 40 ADC regions, which spread from Tiriki East to Tiriki West Divisions. A representative sample of members and leaders, both males and females, was used. Thirty percent of the 40 regions were studied, that is 12 regions. Twelve regions were used because in many educational research projects, small samples are more appropriate than large samples. A small sample also provides more knowledge than a study with only shallow information on a large scale, (Borgand Gall, 1979).

Table1. Sampled Regions for the Study, Membership and Leadership Composition

\begin{tabular}{|c|c|c|c|c|c|c|c|c|}
\hline No & Region & \multicolumn{2}{|c|}{ Males } & \multicolumn{2}{|c|}{ Females } & \multicolumn{2}{|c|}{ Total } & Remarks \\
\hline & & Mbrs & Ldrs & Mbrs & Ldrs & Mbrs & Ldrs & Women \\
\hline 1. & Boyani & 100 & 09 & 320 & 12 & 420 & 21 & members \\
\hline 2 & Iriva & 350 & 27 & 780 & 36 & 1,130 & 63 & \\
\hline 3 & Mugango & 77 & 01 & 255 & 02 & 332 & 03 & leaders are \\
\hline 4 & Giminoi & 164 & 04 & 345 & 05 & 509 & 09 & \\
\hline 5 & Gisamagi & 454 & 40 & 1,980 & 50 & 2,434 & 90 & majority \\
\hline 6 & Bahati (Sabatia) & 1,450 & 80 & 2,250 & 100 & 3,500 & 180 & \\
\hline 7 & Jepsaga & 100 & 06 & 280 & 09 & 380 & 15 & \\
\hline 8 & Kilindilu & 160 & 12 & 280 & 25 & 440 & 37 & \\
\hline 9. & Ibwali & 145 & 12 & 300 & 15 & 445 & 28 & \\
\hline 10 & Isigiri & 107 & 08 & 399 & 10 & 506 & 18 & \\
\hline 11 & Jerende & 205 & 24 & 1,200 & 30 & 1,405 & 54 & \\
\hline 12 & Semagi & 477 & 40 & 2,550 & 50 & 3,027 & 90 & \\
\hline & Total & 3,789 & 263 & 10,939 & 344 & 14,728 & 608 & \\
\hline
\end{tabular}

Source: (Inzai, Incharge of Registry Department 2011)

Random sampling was employed in each region to select female member respondents. Purposeful sampling was also used in each region basing on the above statistics to select female leaders with knowledge and insight on ADC. In sampling populations, a minimum of 50-100 can be used in major groups; a sample of 20-50 can be used in minor groups (Kothari and Pals, 1993). Using this method, the researcher used leaders as a major group hence interviewed 96 female leaders, 30 male leaders, 50 female members, 1 Archbishop, 1 GS and 1 Mother Mission (MM). These three posts only have one leader each. The total respondents were 179. Kothari and Pal's method was suitable because the numbers were too big as shown in the table above hence. 
The stratified random sampling and purposive sampling techniques were used. Stratified random sampling technique involved dividing population into homogenous sub-groups and then making a simple random sample in each group. The sample was selected in such a way to ensure that certain sub groups in the population were presented in the sample in proportion to the number in the population. This method is appropriate when the researcher is interested in issues related to gender, race or age. (Kombo and Tromp, 2007). Members were stratified into males and females. Purposive sampling technique involved a sample of leaders who hold various posts in the selected regions both males and females. This method ensured that the leaders from all the regions were well represented in the sample. This purposeful sampling helps one to hand pick individuals due to their experience and insight on the subject of study (Kinoti, 1998).

\section{INSTRUMENTS FOR DATA COLLECTION}

Data was collected using questionnaires, oral interviews, participatory observation, document analysis and focused group discussion.

\subsection{Questionnaires}

Questionnaire was preferred for its suitability to this study. It was suitable as method of data collection because it allowed the researcher to reach a lager sample within limited time. This method allowed combining the flexibility of the interview method and the fixed standard order of the questionnaire .By using this, a questionnaire is constructed setting out all the questions and noting down the response (Kinoti 1998).

\subsection{Data Collection Procedure}

The researcher visited ADC Archbishop for permission to visit various churches for data collection. Various churches were visited for carrying out oral interviews and documents analysis to ascertain the required information by the researcher on the subject of research

\subsection{Data Analysis}

Data for this study was analyzed using descriptive or qualitative analysis. This method was used to describe, explain and generally work with the data around each of the major topics. This was done including all information relevant to the questions answered throughout the research that is answering research questions with an aim of reporting the findings in detail. This was done in a narrative form to provide a complete picture of the activity or event being described. The second method to be used in data analysis was quantitative data analysis. This involved calculating the number of regions to be used in the research, how many female leaders, male leaders and calculating percentages of the number of respondents from the responses received through oral interview, questionnaire and focus group discussions. This was done on various issues such as prophecy, faith healing, women membership composition, women in leadership roles and reasons for attraction to ADC. All of these numbers become statistics of one sort or another and provide valuable backup for conclusions that are more strictly quantitative, (Kinoti, 1998).

ADC Constitution (1950 Revised 2001).

\section{REFERENCES}

Allan H. Anderson (2001): African Reformation: African initiated Christianity in the twentieth Century Africa World Press. Inc.

Gall, M.P.Borg, W; R \& Gall J.P (1996) Educational Research an introduction. New York Longman publishers.

Gay L.R (1981) Educational Research, competencies for analysis and evaluation.

Kinoti Hannah. W. (1996) A handbook of social Research method. The National Council of Churches of Kenya Nairobi.

Kombo, D.L. \$ Tromp. L.A (2006) Proposal and thesis writing. An introduction. Nairobi, Kenya Pauline publications.

Mahero J.S (2009) $60^{\mathrm{TH}}$ Anniversary of ADC introduction \& historical background.

Mbiti J.S (1969): African Religion and philosophy. East African Publishers Ltd. Brick Court Woodwale Grove Mpaka Road Westlands Nairobi

Mbiti J. S (1975): Introduction to African Religion. 
Mugenda M.Olive \& Mugenda G. Abel: Research methods Quantitativeand qualitative Approaches African centre for technology Studies Acts NBI, Kenya

Nandi M.O.J (2001): Theological and historical background Dini Ya Musambwa PhD. Thesis Department of Religion Maseno University.

Nandi. O.M.J. (1993): Theological and historical background of the Jerusalem Church of Christ MA thesis Department of Religion University of Nairobi.

Nyimbo za Injili (1959) Evangel Publishing House. Nairobi Kenya

Sekaran (2004): Research Methodology in Business.

The Holy Bible. New Version International.

Turner H.W. (1977): Bibliography of New religious movements in primal Societies Boston, Prentice Hall.

\section{AUTHORS' BIOGRAPHY}

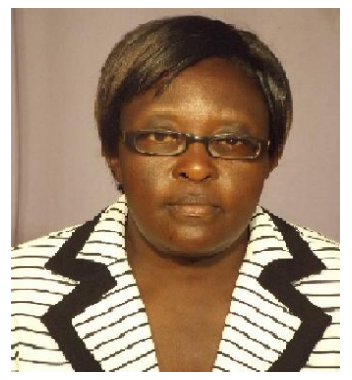

Kima Pamela Vidembu, holds a MA in Religion and is currently pursuing a $\mathrm{PhD}$. She is a high school teacher where her current responsibility is Director of Studies and Christian Union patron. She is also a part time lecturer at Masinde Muliro University of Science and Technology. She has published in a scholarly book a synopsis of African Divine Church in Kenya with special reference to Vihiga County and a Journal on the historical background of African Divine Church. She is a member of Association of African Religion studies (AARS). 